\title{
EVOLUTION OF GOLPAZARI-HUYUK KARST SYSTEM (BILECIK-TURKEY): INDICATIONS OF MORPHO-TECTONIC CONTROLS
}

\author{
Mehmet Ekmekci and Lütfü Nazik
}

\begin{abstract}
The Golpazari-Huyuk karst system is located in the Central Sakarya Basin whose geomorphologic evolution is mainly controlled by the Post-Miocene epirogenic continental rise. Drastic change in the drainage pattern and dissection of the carbonate platform were the major consequences of this tectonic movement. Rapid incision of the Sakarya river changed the position of the erosion base which consequently distorted the direction of surface and subsurface flow. The Golpazari and Huyuk plains are two topographically distinct, flat bottomed geomorphic features separated by a carbonate rock relief. The difference in elevation between these $10 \mathrm{~km}$ distant plains is $350 \mathrm{~m}$. Morphological, geological and hydrological behavior of the plains suggests that the both have functioned as closed basins connected to each other through subsurface flow paths. Drainage has changed from subsurface to surface after the emplacement of the Sakarya river into its modern course. In this study, the authors suggest a conceptual model to reconstruct the hydrological-geomorphological processes that have been effective in the evolution of this karst area. The methodology is based on the records preserved in the morphological and sedimentological archives as well as the hydrogeological setting in the study area. According to the suggested model, the present landscape which exhibits a late stage of karstification has evolved in three main phases, after an initial stage attributed to Lower Miocene. The first phase represents karstification of carbonate rocks of Jurassic age at the Huyuk area and the limestone of Paleocene age at the Golpazari area. This region must have been significantly elevated from the karstification (erosion) base. The geomorphologic and drainage setting reveal that the karstification was controlled mainly by major drainage elements in Late Miocene-Early Pliocene.The second phase is characterized by the uplift of the region and the subsequent rapid incision of drainage during the pluvial period thereby the ponors that drained the polje were completely clogged and the polje turned out to be a lake in late Pliocene-Early Pleistocene. The third phase consists of a re-arrangement of drainage pattern and related geomorphologic processes mainly controlled by tectonic movements during Early Pleistocene. Consequently, surface drainage started in the Golpazari lake. Meanwhile Sakarya river incised its bed through the fractured carbonate rocks, capturing also the Huyuk depression complex.
\end{abstract}

Keywords: geomorphology, tectonics, hydrogeology, karst evolution, Turkey.

\section{Introduction}

The recognition of a great variety of types of karst in Turkey for the last decade required a closer look and a more detailed study of the karst development according to the study 
by Ekmekci (2003) that related the occurrence of different karst types to the neotectonic evolution of Turkey as described by Sengor et. al. (1985), the karst forms are regarded as important archives of records of geomorphic evolution. The Golpazari-Huyuk karst system is such an archive providing us with the evidences of karst evolution in the Sakarya river basin, northwest portion of Central Anatolia (Fig. 1).

The Golpazar1-Huyuk Karst System is located at the eastern part of the Marmara Region in the northwestern Anatolia. Golpazarı part of the system is known as the Golpazari Plain having a surface area of about $35 \mathrm{~km}^{2}$. It is northwest-southeast elongated in shape with a longer axis of about $12 \mathrm{~km}$. The Huyuk Plain is situated only $7 \mathrm{~km}$ to the west of the Golpazari plain (Fig.1). The Huyuk plain is rather a sort of combination of flat areas separated by hums.

Regarding its location in the neotectonics framework, Central Anatolia represents the weakly active tectonic province, called the 'Ova Regime' by Sengör et. al. (1985), since the Lower Miocene (Fig. 2). Weakly active tectonic regime implies that the region has been affected by a weak, but probably steady tectonic activity, causing a general slow uplift. On the other hand, Central Anatolia should not be considered homogeneous in the sense of the tectonic effect, particularly since the Upper Pliocene. The northwestern part, where the Golpazari-Huyuk Karst System is located, is under an extensional effect of lower magnitude (see Fig. 2).

According to the description by Ekmekci (2003), this portion of Central Anatolia is represented by the following general characteristics:

- Lithology: relatively thin formations due to the continuous uplift and subsequent erosion since Early Miocene; massive carbonate rocks of high degree of diagenesis/low metamorphosis; rocks exposed are generally of Mesozoic age.

- Tectonics: slow but almost continuous, uplift in general

- Source of Energy Gradient: uplift and associated entrenchment of major rivers. Black sea level change has secondary effects.

- Erosion Base: impervious units underlying the Lower Paleocene carbonate rocks.

- Stage of Karst: former mature karst is eroded to a great extent and dissected intensely by faults and rivers to form smaller karst massifs and thus it lost its extensive recharge areas, point input systems, extensive throughput controls including vadose and phreatic zones and consequent output controls as large springs. Karst features such as poljes, dolines and uvalas can be hardly recognized as their characteristic morphology is significantly destroyed by erosion.

- Type of Karst: shallow, mainly subhorizontal to sub vertical: dissected by faults and rivers in general. Karstification continuous since Miocene .

- Aquifer Characteristics: depend mainly on the extent of the carbonate rock. Karst springs have discharges in the order of some tens of liters per second at the maximum.

\section{Geological setting and neo-tectonic evolution}

The information on the geological setting of the study area is based mainly on Goncuoglu et. al (1996), Goncuoglu et. al (2000) and Yigitbas et. al (2004) . The simplified geological map of the study area is given in Figure 3. The oldest lithological unit in the study area is the recrystallized carbonate rock of Upper Permian age. This unit forms the high rock mass that topographically separates the Golpazari plain from the Huyuk Plain. The 


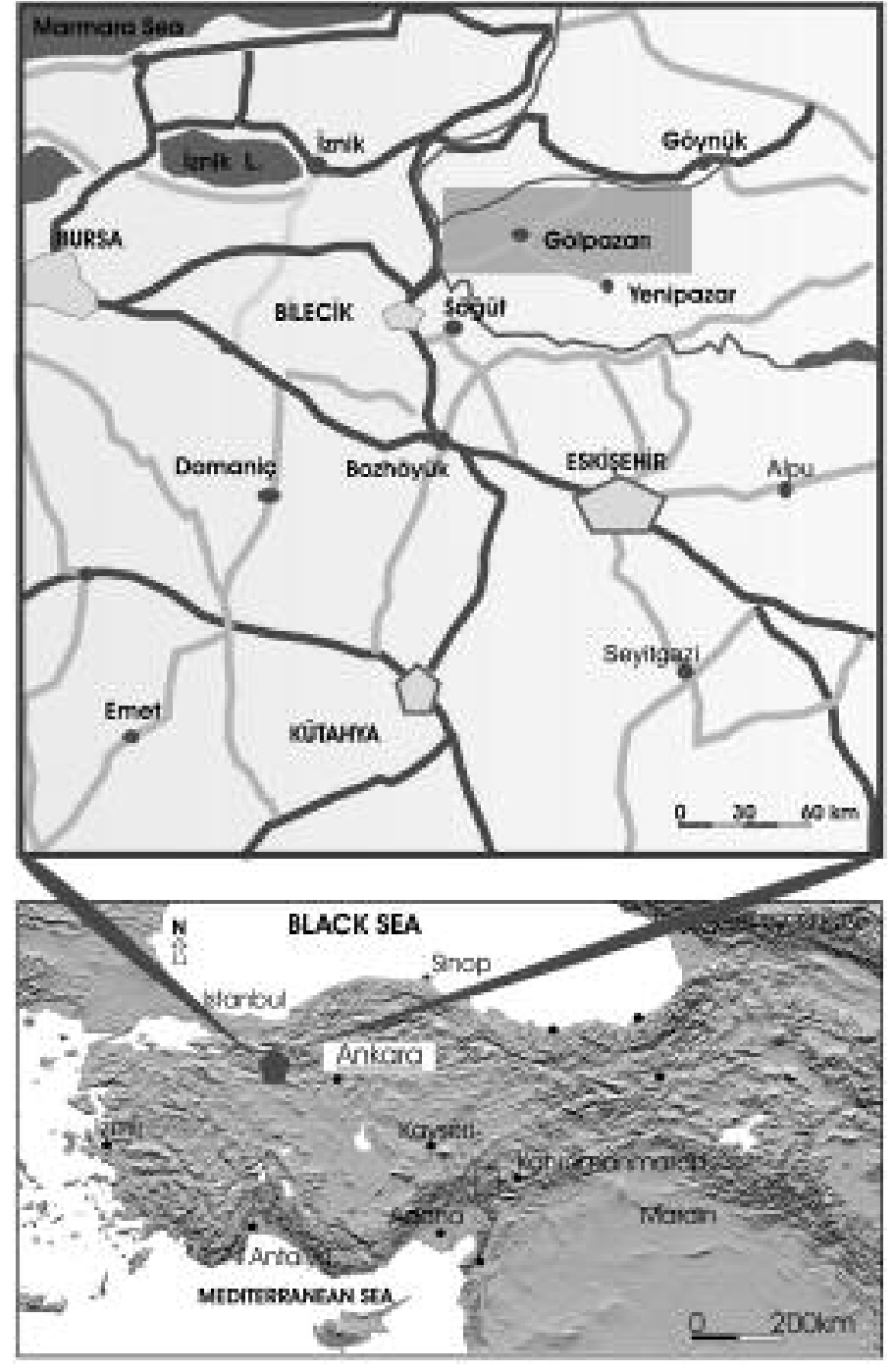

Figure 1. Location Map of the Study Area

Permian aged carbonate rock unit is overlain by the recrystallized Jurassic limestone known as the Bilecik Limestone. The Bilecik limestone borders the Golpazari plain only at the west while it surrounds the Huyuk plain almost along its whole periphery. Cretaceous units overlying the Jurassic limestone are exposed at the western and northwestern part of the Golpazari plain as narrow stripes. Goncuoglu et.al. (1996) refer to the Jurassic and Cretaceous aged units as the 'para-authocthonous' cover as they overlay the metamorphic basement in the region. The Cretaceous formation of the para-authocthonous units is composed of flysch. All Pre-Tertiary rocks are overlain by the 'authocthonous cover' comprising the Kızılçay Formation (terrestrial mudstone) of Upper Cretaceous-Paleocene age; Selvipinar (reefal) Limestone of Paleocene age; and the younger (Eocene) clastic (sandstone, conglomerate, mudstone) formations. The 


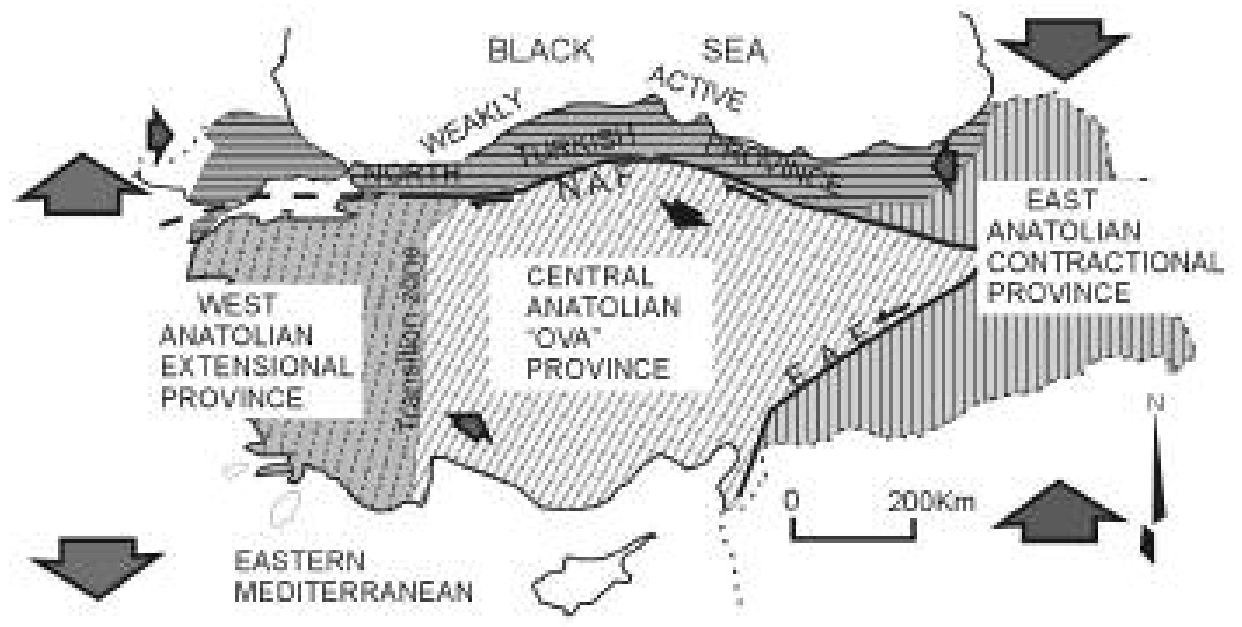

Figure 2. Tectonic Regimes in Turkey defined by Sengor et. al., 1985, (with permission)

Golpazari plain is surrounded mainly in south, east and northeast by the Paleogene aged Kızılçay formation and the overlying Selvipinar limestone. The clastic unit of Eocene age crops out mainly at lowlands in south of the study area and around Huyuk plain. The flat bottom of the Golpazari and the Huyuk plains is covered by alluvial deposit of Quaternary age.

\section{Geomorphological setting}

The present geomorphological appearance of the region that includes the study area is outlined below mainly based on the description by Nazik et. al., (2001). Relief systems of Miocene, Pliocene and Quaternary are distinguishable in the study area. It is possible to recognize the Miocene Peneplane of the Anatolia at the highest part of the reliefes, between the altitudes of 900 and $1700 \mathrm{~m}$ a.s.l. This large difference in altitude is attributed to normal faults developed during the neotectonic period and the contrasts in susceptibility of lithologies to erosion which took place during Pliocene and Quaternary. The Miocene surfaces that have been uplifted well to form the plateaus in the region have been dissected by faults and rivers and karst well developed where the plateaus are formed by carbonate rocks.

However, the general geomorphological appearance of the area is characterized mainly by the Pliocene relief system. The morphological setting of this period has been developed around the heights of Miocene system and the paleo-subsequent valleys crossing these highlands. The paleo-subsequent valleys have been developed either along tectonic lines or lithological boundaries.

The Pliocene relief system is recognizable between altitudes of $400-850 \mathrm{~m}$ a.s.1. and represented by east-west paleovalleys/suspended valleys, fluviokarstic poljes, uvalas and caves as well as erosional surfaces. Figure 4 shows the cave distribution in the region. As depicted in the figure caves are mainly found in the Mesozoic carbonate rocks. Although caves have been developed also in other carbonate rocks of younger age, they have been 
eroded leaving only entrances behind. Since three distinct morphological base levels were defined for the morphological forms, Nazik et.al. (2001) state that it is very difficult to speculate about a general erosional base for morphological development during this period. However, it can be suggested that the erosional base level which was effective in the morphological development of the area including the Golpazari-Huyuk system was the Bilecik-Yenisehir-Bursa Neogene Basin, because all paleo-valleys and fluviokarstic poljes are directed toward this basin.

In the Quaternary period, the Pliocene relief system was drastically rearranged and the area gained a new morphologic setting. The Sakarya river incised its valley during Quaternary and thus played a major role in the development of the landforms that gave today its general appearance to the area. The entrenchment of the Sakarya is considered to be the primary agent that dissected the paleo-basins including the Golpazari basin (Nazik et.al., 2001). The characteristic forms of the Quaternary period are canyons, gorges, immature erosion surfaces, suspended valleys, river terraces, travertine deposits, spring-caves, and periodically active caves.

The drainage network was developed to a great extent in the Pliocene period. The paleovalleys oriented toward the major basins, in the direction of northeast-southwest and northwest-southeast, were captured by the recent tributaries of the Sakarya river that were developed during Quaternary mainly in the direction of north-south.

Nazik et.al. (2001) also state that no extensive karstification is observed in the region, because no extensive carbonate rock mass exists. They point out that karstification is hindered by the impervious units underlying and surrounding the carbonate rocks. They also suggest that karstification must have started during Pliocene and must have been enhanced during the Quaternary period owing to the entrenchment of the Sakarya river. However, Nazik et.al. (2001) believe that the magnitude of enhancement of karstification has not been as high as the non-karstic geomorphological re-juvenation in general, and that is why 'scattered karst' characterizes the region. So, they state that carbonate rocks must have been karstified after they had been dissected. Whereas, Ekmekci (2003) postulates that the scattered karst was not developed on dissected carbonate blocks but on the contrary, the previously developed karst had been dissected to gain the present appearance, because the source of energy gradient required for karstification can not be otherwise established. The conceptual model suggested herein to explain the evolution of the Golpazari-Huyuk karst system, provides evidences to both morphological evolution of this specific region and to the karst evolution model suggested by Ekmekci (2003) to explain the great variety of karst types in Turkey.

\section{Hydro-geomorphological description of the system}

Structurally, the Golpazari plain is located along the axis of an anticline which is extended parallel to an overthrust of the Cretaceous units in the southeast (see Fig. 3). The Akcay stream that supplies the hydrological input into the Golpazari plain follows the axis of the anticline. Akcay stream enters the plain from the northeastern edge and leaves it through a gorge in the south flowing along the southern edge of the plain. The upstream discharge rate of this intermittent stream is about $45 \mathrm{l} / \mathrm{s}$ while it reaches up to $130 \mathrm{l} / \mathrm{s}$ downstream due to the spring discharges as well as groundwater contribution along the stream course on the plain. A periodic shallow lake is located at the western portion of the plain. The lake 


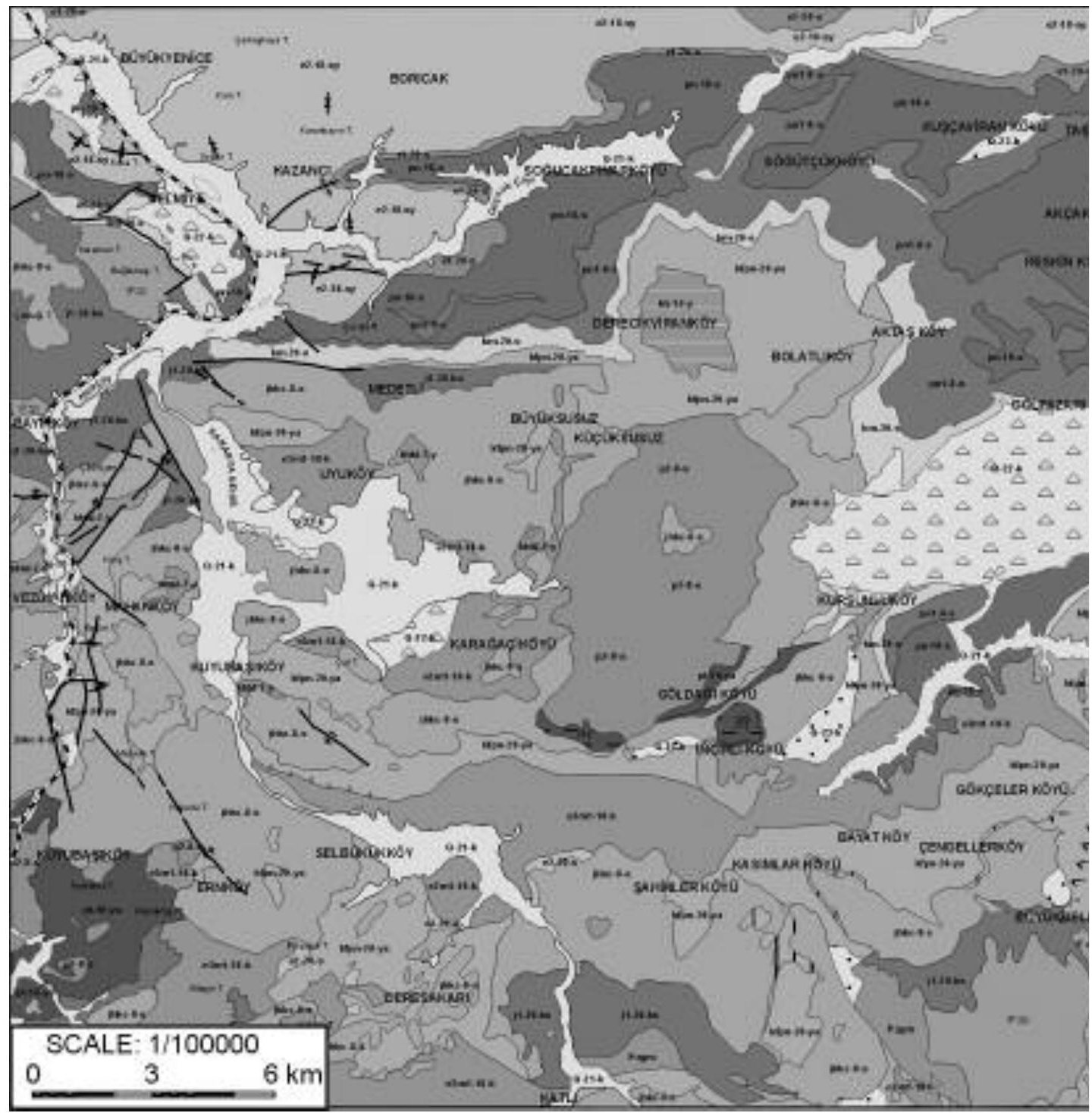

known as a swamp is drained via a man-made canal. All waters collected from the plain are drained by the Akcay stream into a larger tributary of the Sakarya river in the south which joins the Sakarya river, the main drainage element in the region (Fig. 5).

The Huyuk plain on the other hand, is semi-circular in shape. The Sakarya river forms its linear boundary on the west. Unlike the Golpazari plain, the bottom of the Huyuk plain is not even. There are two hums of limestone and a tumulus (Huyuk in Turkish).

Regarding the groundwater potential of the Golpazari plain, the State Hydraulic Works of Turkey (DSI) has drilled exploration boreholes which have revealed that not only the 


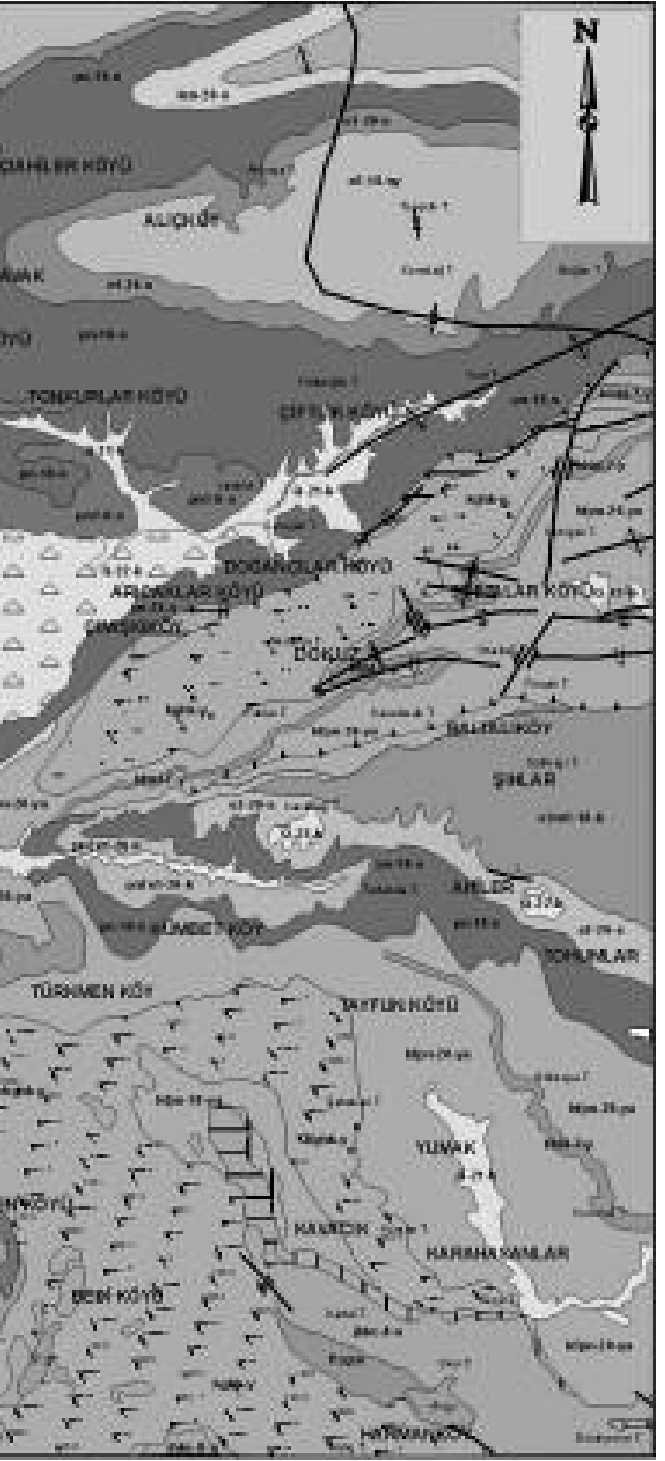

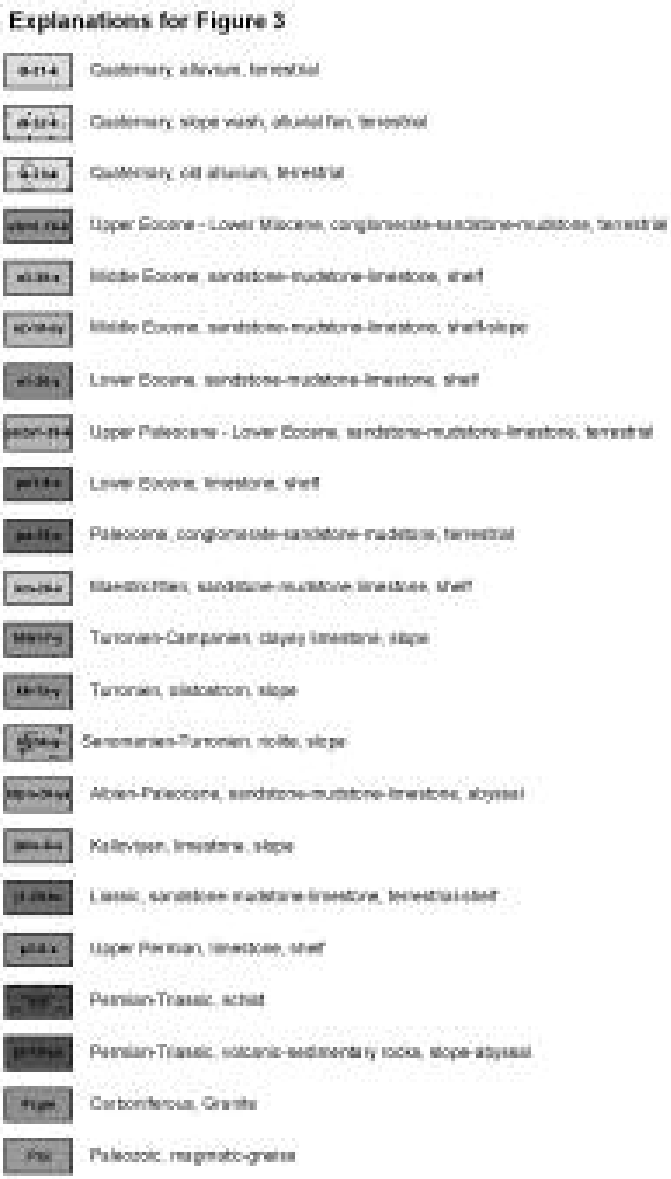

thickness but also the composition of the alluvium in the plain has spatial variation. The variation in both thickness and composition (in terms of grain size) is east-west oriented, having the thickest part in the west and the thinnest part in the east. Similarly, the alluvial fill in the west is composed of fine-very fine material mainly clay; whereas, the gravely-sandy material lie close to the east (Fig. 6). The cross-section shown in Figure 7 also illustrates that the coarse grain alluvial material in the eastern portion of the plain has been dominating only at particular horizons and this coarse grained alluvium is underlain again by fine material. 


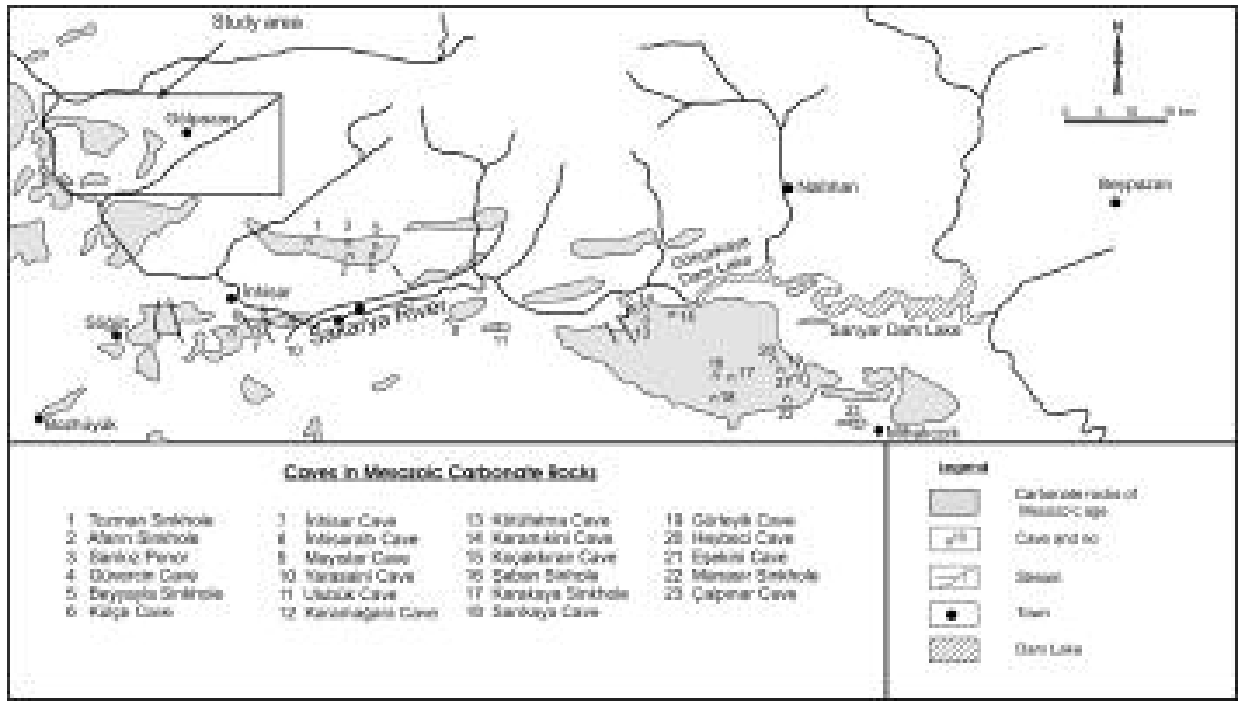

Figure 4. Distribution of caves in the region (modified after Nazik et. al., 2001)

As depicted in Figure 7, the lithology underlying the alluvial fill in the Golpazari plain is composed of the Jurassic limestone in the west, the Cretaceous flysch in the central part and the Paleogene aged units in the east. In the Huyuk Plain, it is possible to distinguish the alluvium of the recent Sakarya river along the western boundary from that covers the central and eastern part of the plain which suggests that the plain is not a flood plain of related to the Sakarya river. The Huyuk plain is surrounded mainly by Jurassic carbonate rocks with some outcrops of Paleogene flysch. The lowest part of the Golpazari plain is in the west at an elevation of $500 \mathrm{~m}$. The central part has an elevation of about $550 \mathrm{~m}$. The difference in elevation between the Golpazari plain and the Huyuk plain which is only $10 \mathrm{~km}$ to the west of the Golpazari plain is about $350 \mathrm{~m}$, having the Huyuk plain an average elevation of $200 \mathrm{~m}$ a.s.l. The lowest part of the Huyuk plain is about $150 \mathrm{~m}$ a.s.l. However, as indicated above, the bottom of the Huyuk plain is not even. The hums indicate that the plain is a combination of more than two depressions.

\section{Indicators of karst in the Golpazari-Huyuk plain system}

Some morphological, geological and hydrological characteristics of the GolpazariHuyuk plains are obvious indicators of karst. Beside the landscape, the geomorphologic features observed at and around the plains suggest that they functioned as an interconnected karst system in the past. Both plains have the characteristics of karst depressions; the Golpazari plain being a paleo-polje and the Huyuk plain having the characteristics of a rather fluvio-karstic feature. The term paleo-polje is used here to imply that the hydrogeological function of this morphologic feature is ceased and the indication relies upon the geomorphologic, geologic and hydrologic integrity. The northern part of the Golpazarı paleo-polje is marked by a series of cave entrances very close to the alluvium covered flat bottom. The caves are not longer than a few meters. The lowest part of the paleo-polje was being flooded in wet season before drainage canals were excavated in 


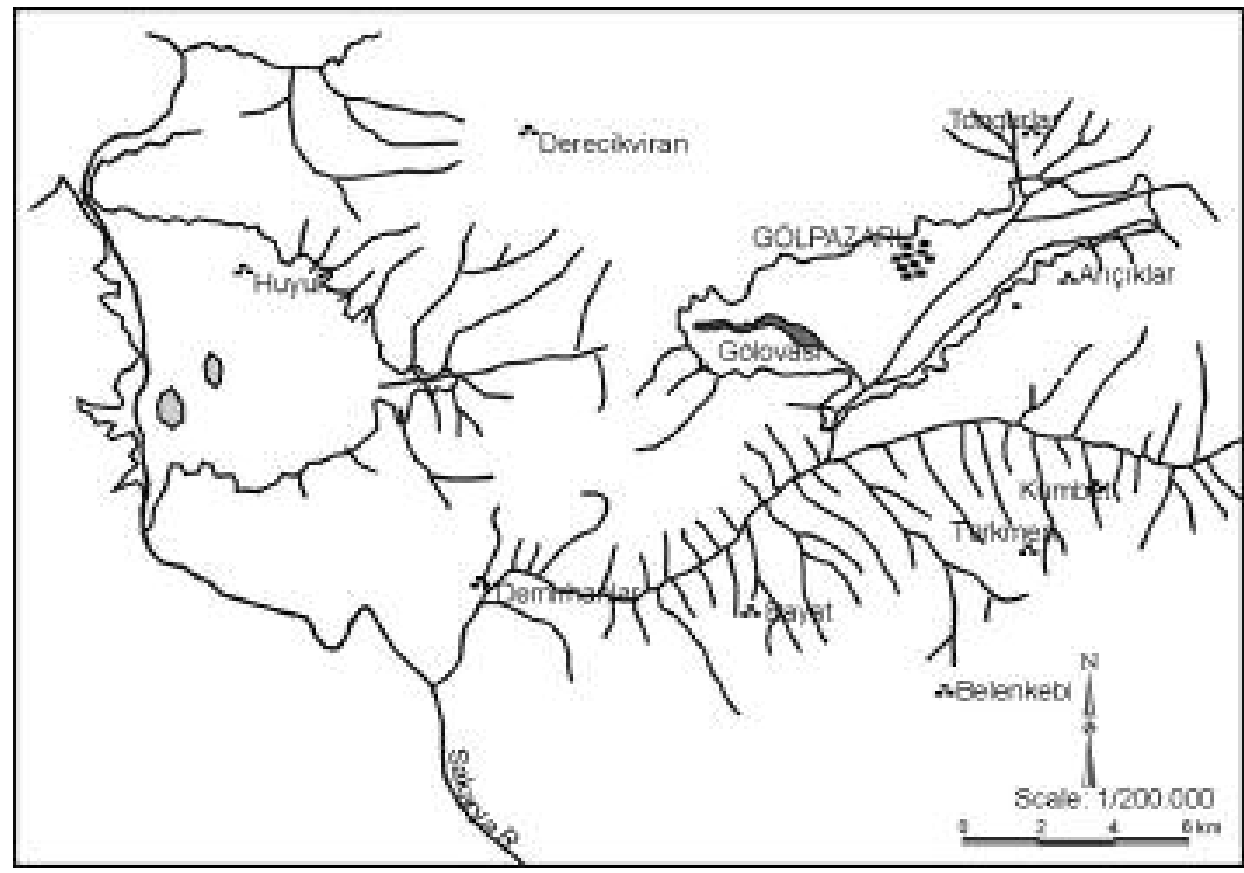

Figure 5. Drainage Pattern in the Study Area

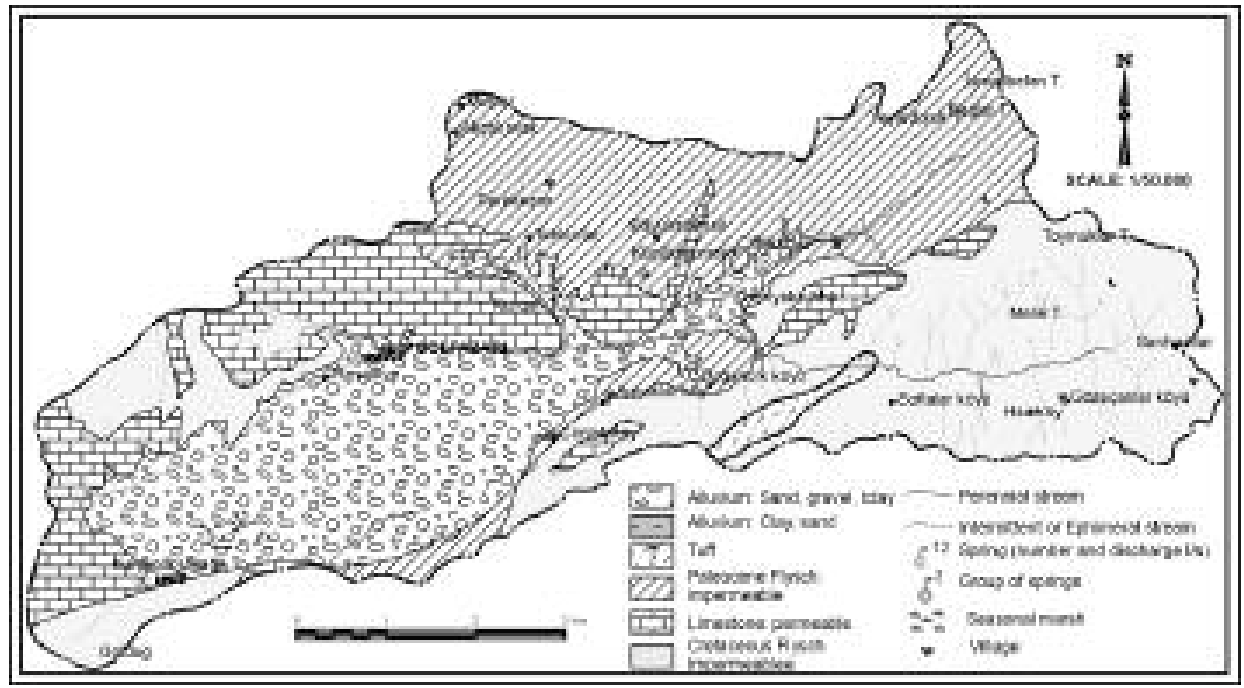

Figure 6. Hydrogeological Map of the Golpazari Plain (from DSI, 1974) 


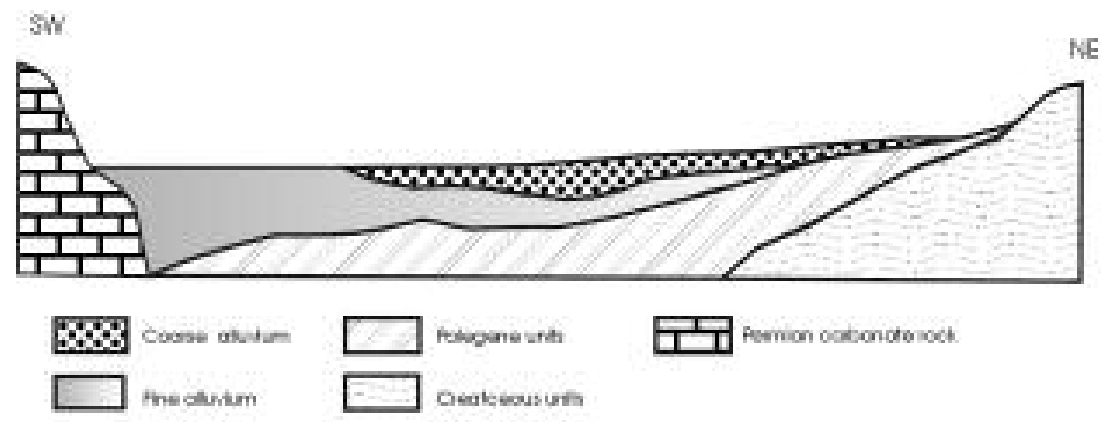

Figure 7. Simplified Geological Cross-Section of the Golpazari Plain (modified from DSI, 1974)

1960's. This part of the paleo-polje most probably represents the area where the largest ponor(s) were located. Drainage of the polje must have been by subsurface drainage through these ponors. The Akcay stream, which enters into the polje from the northeast, flows in a rather young entrenched valley following the emplacement of the Sakarya river. The rapid incision of the Sakarya river valley changed the drainage system both in terms of pattern and direction. Several suspended valleys that were located in the area hint at the change in drainage system. As a consequence of this change, a recently developed tributary of the Asagisurumdere stream captured the polje from the south. The Huyuk depression, on the other hand seems to have been completely captured directly by the Sakarya river as it was emplaced on the western border of the depression. The gorges that allow the Sakarya river flow through the Huyuk depression have the character of caves whose roofs have been collapsed. Such collapses in the area seem to be triggered by tectonics rather than weakening in strength due to erosion. However, all these observations require a more detail study of the gorges, suspended valleys and the surrounding plains.

\section{Reconstruction of evolution of the karst system}

The evolution of the Golpazari-Huyuk karst system was reconstructed in 4 major stages as follows.

Initial Stage: As indicated also in the geological setting, the Eocene aged lithologies form the youngest rocks in the area. This is because the region has not been invaded by marine waters since the Early Miocene, although some portions of the region represent limnic, fluviatile and other terrestrial facies, particularly during Late Miocene and Pliocene (Sengör et.al., 1985). Hence, the Miocene period, which corresponds to an erosional phase, can be regarded as the initiation phase for karstification. Keeping in mind that the rocks that can be karstified are of Lower Paleogene, Jurassic and Permian age, and that all these rocks were covered by non-carbonate clastic lithologies of PaleogeneEocene age, the initial stage for the karst evolution may be started when non-carbonate rocks overlying the Lower Paleogene aged Selvipinar limestone were eroded and the 


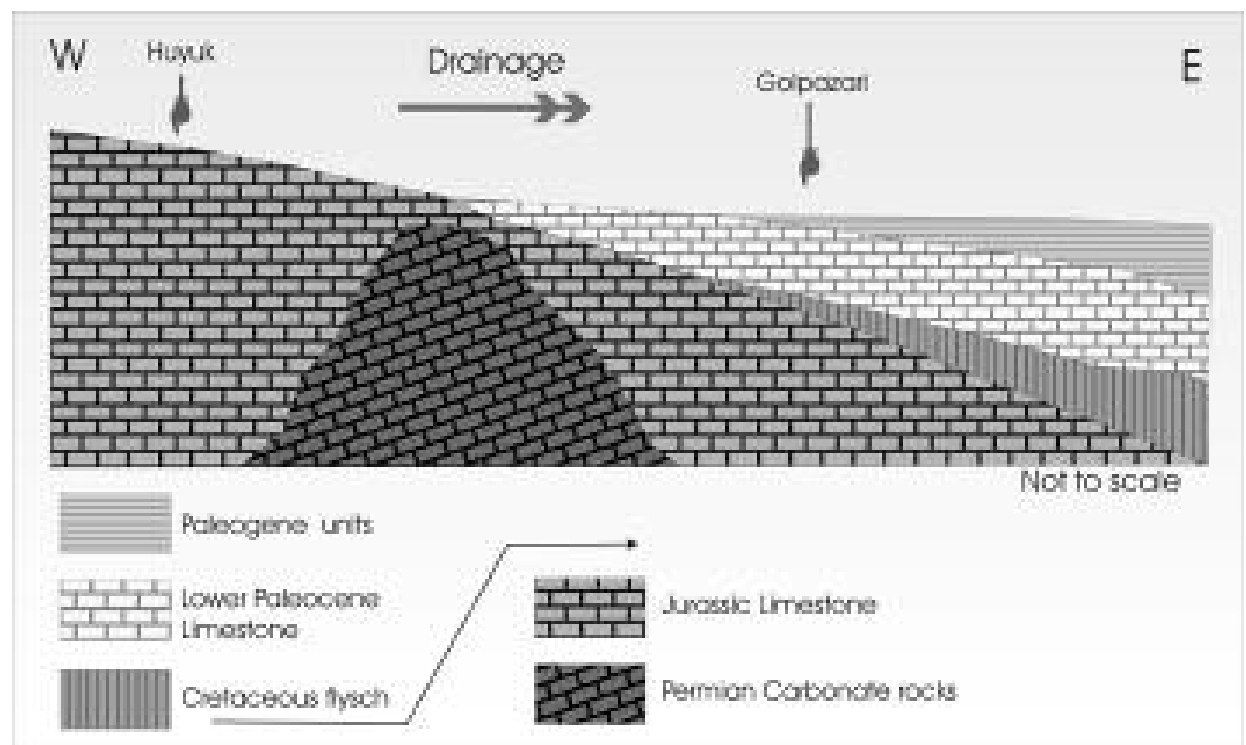

Figure 8. Schematic Illustration of the Initial Stage (Early Miocene) of the karst system

karstifiable rocks were exposed to the atmospheric weathering. The geological setting was reconstructed according to the paleogeographical development in the region and illustrated in Figure 8. As depicted in the figure the Golpazari area was completely covered by the Selvipinar limestone having a relief with an average elevation of about 2000 $\mathrm{km}$ dipping toward eastern Anatolia in Early Miocene (Sengor et. al., 1985). The seas that were occupying eastern and northern Anatolia were the main erosion base level for the drainage systems developed throughout Anatolia. With a particular regard to the study area, the drainage system developed mainly toward the Black sea.

Stage of Closed Drainage (Development of Karstic Depressions): During Middle Miocene-Pliocene period the topographic surface was lowered as a consequence of the uplift in Eastern Anatolia and subsidence in Western Anatolia. The topographical surface was almost at the sea level at that period, forming some flat areas of closed drainage. The geological setting suggests that the Jurassic and the Permian aged carbonate rocks formed the heights on the western and central parts of the study area respectively (Fig. 9). Therefore, exposure to atmospheric conditions and the consequent karstification of these rocks was much earlier than those existing at the eastern part. The rocks of Paleogene age that covered the Jurassic and older rocks have been eroded during or before Early Miocene. Karst depressions most likely in the form of dolines were developed first. As karstification proceeded, dolines were combined to form a large uvala which is known as the Huyuk plain today. The eastern part of the study area, viz. the Golpazari plain area was covered by the Lower Paleogene aged Selvipinar limestone which at this stage was exposed to karst processes. The flat topography which gave rise to closed drainage in some parts, enhanced these processes and resulted in formation of 
large karstic depressions. The Golpazari was developed to be one of the important karst poljes along the syncline axis extending NE-SW (Fig. 10).

Subsurface drainage of both the Huyuk and Golpazari karst depressions were initiated at this stage toward the contemporary erosion base which was most probably the Goynuk river in the north.

Stage of Drainage Reversing (Enhancement of Subsurface Connection): The uplift of Eastern Anatolia and the subsidence of Western Anatolia associated to the westerly migration of the Anatolian micro-plate (Sengor et. al., 1985) changed the direction of regional drainage system from west to east. This regional change also affected the drainage in the Golpazari-Huyuk system. Subsurface connection between the Golpazari polje and the Huyuk karst depression was enhanced at this stage. The largest ponor at the bottom of the polje was located at the west edge where the plain is still being flooded in wet seasons. This ponor drained the polje into the Huyuk system. Karst at the western portion of the Golpazari polje was developed within the Jurassic and Permian aged carbonate rocks while the Lower Paleogene Selvipinar limestone was karstified at the eastern part. Drainage of the Huyuk karst depression was through another ponor-cave located at the northwestern edge of the depression toward the Goynuk river in the north (Fig. 11). Karst was well developed at this stage. The Selvipinar limestone was significantly eroded and as a consequence, the underlying impervious units became shallower on the east.

Final Stage: Stage of Erosion, Clogging, and Development of Surface Drainage: During Late Miocene and Pliocene, large portions of Western and Central Anatolia were covered by limnic and fluviatile facies. In areas that were inundated by fresh waters, karstification was interrupted while fluvial processes enhanced the physical erosion. Fluvial processes dominated at the Golpazari-Huyuk system at this stage. Having the Selvipinar limestone significantly eroded and the underlying impervious units became shallower at the eastern part of the Golpazari polje, surface drainage became much more pronounced than subsurface drainage. The sediment load brought by the surface waters accumulated these sediments at the lowest part of the polje where the large ponor(s) was located. Ultimately, the sediment load obstructed the ponor(s) and hence started to fill the polje (Fig. 12). Boreholes drilled by the DSI verify this stage as the alluvial fill at the eastern part of the polje is represented by coarse material like gravel and sand while fine to very fine material occupies the ponor site at the western part (see Fig. 7).

Gravels of quartz of fluvial origin that exist on the carbonates separating the two system topographically, indicate that after the ponors were clogged, the water continued to discharge into the Huyuk depression as a surface water flowing over the carbonate rocks separating the two depressions. The Huyuk depression thus received some of the sediment load of particularly finer material. The overflow continued for short period until the Sakarya river incised its new bed also by the effect of tectonics. Likely this happened in Early Pleistocene (Fig. 13).

Several gorges were formed by the effect of these movements, some by collapse of caves as the case in the Huyuk depression. The consequence of the tectonic movements was not only the entrenchment of the Sakarya river in its new bed but also the drainage of basins 


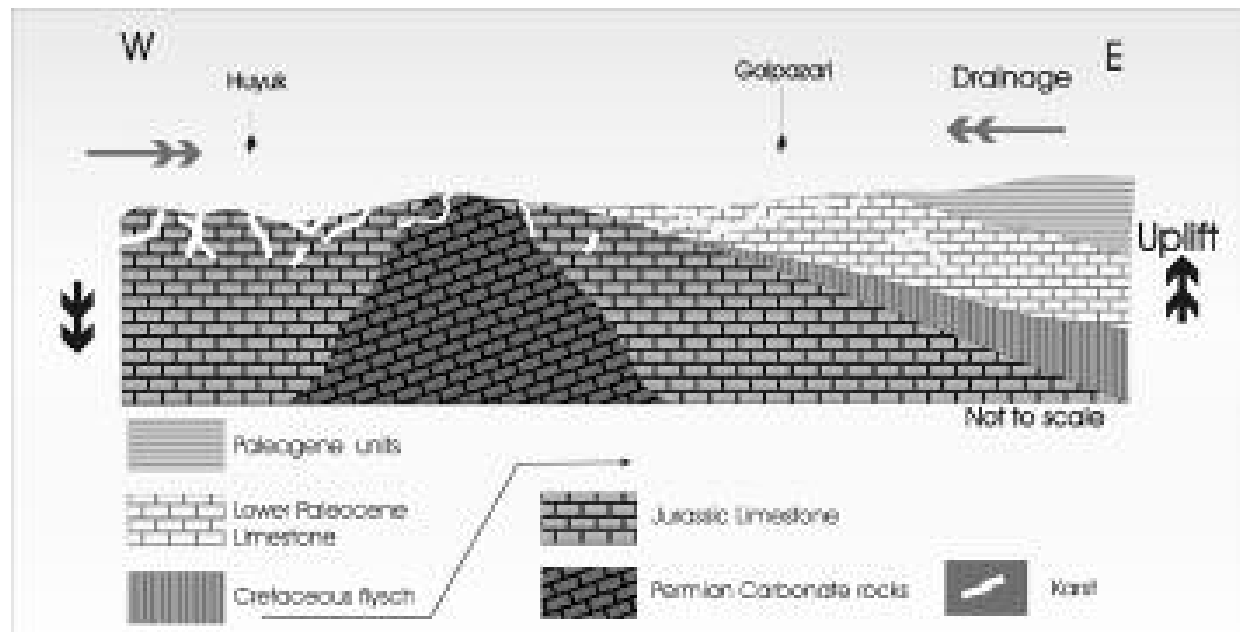

Figure 9. Early Karst Development in Jurassic and Paleocene Limestone During Middle Miocene (?)

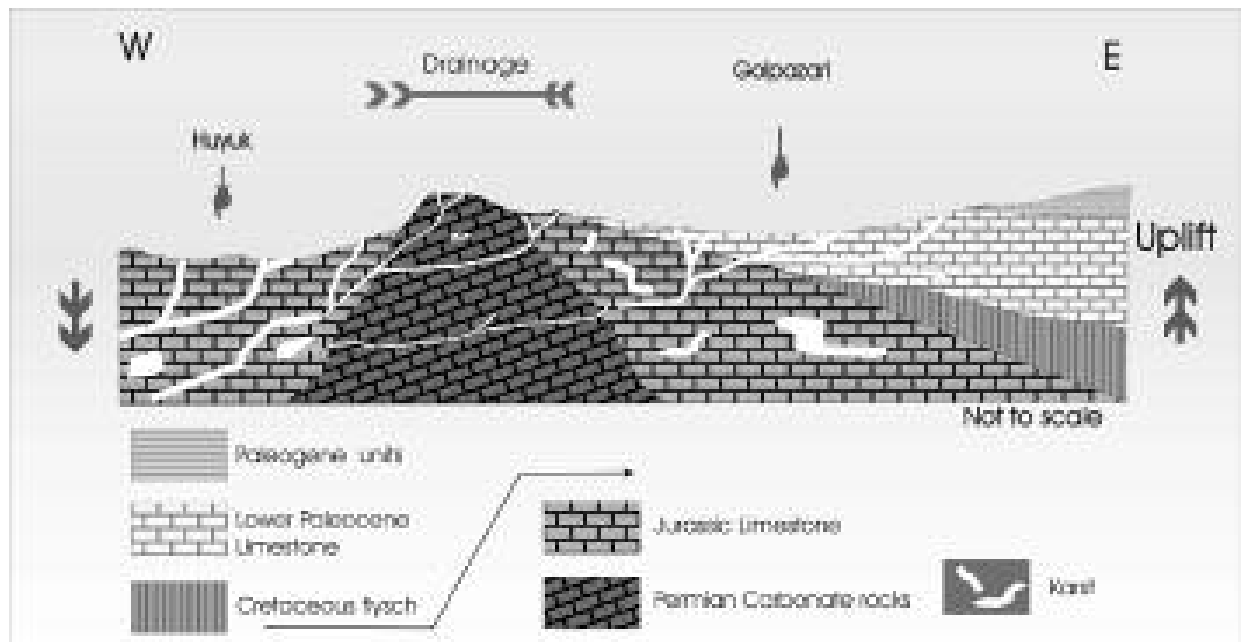

Figure 10. Karst Development Enhanced Due to Continuing Uplift (Late Miocene ?)

in the region was diverted to this new major drainage element. A gorge opened at the southwestern edge of the Golpazari polje and the polje was drained trough this gorge into the new Sakarya river. Similarly the Huyuk depression was captured directly by the Sakarya river which was emplaced within the gorges formed by collapse of caves extending toward the former major drainage element, the Goynuk river.

A model for reconstruction of Golpazari-Huyuk karst system is suggested here in this 


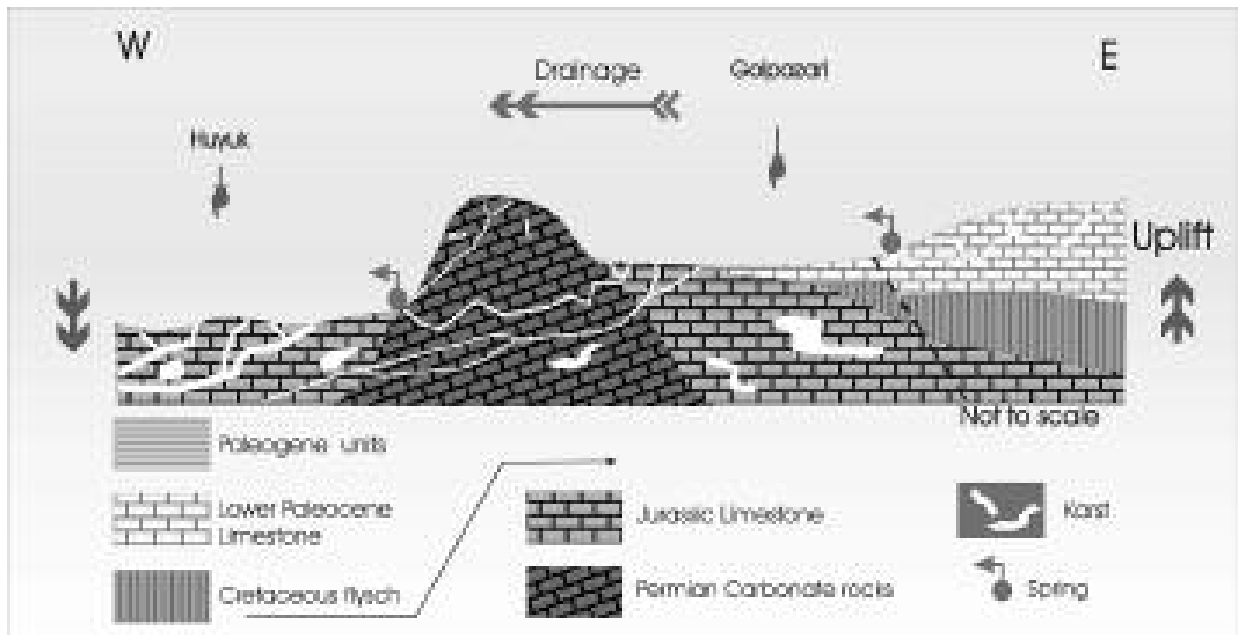

Figure 11. Well developed (Mature) Karst: Enhanced Connection Between Goplazari Polje and Huyuk Depression (Late MioceneEarly Pliocene)

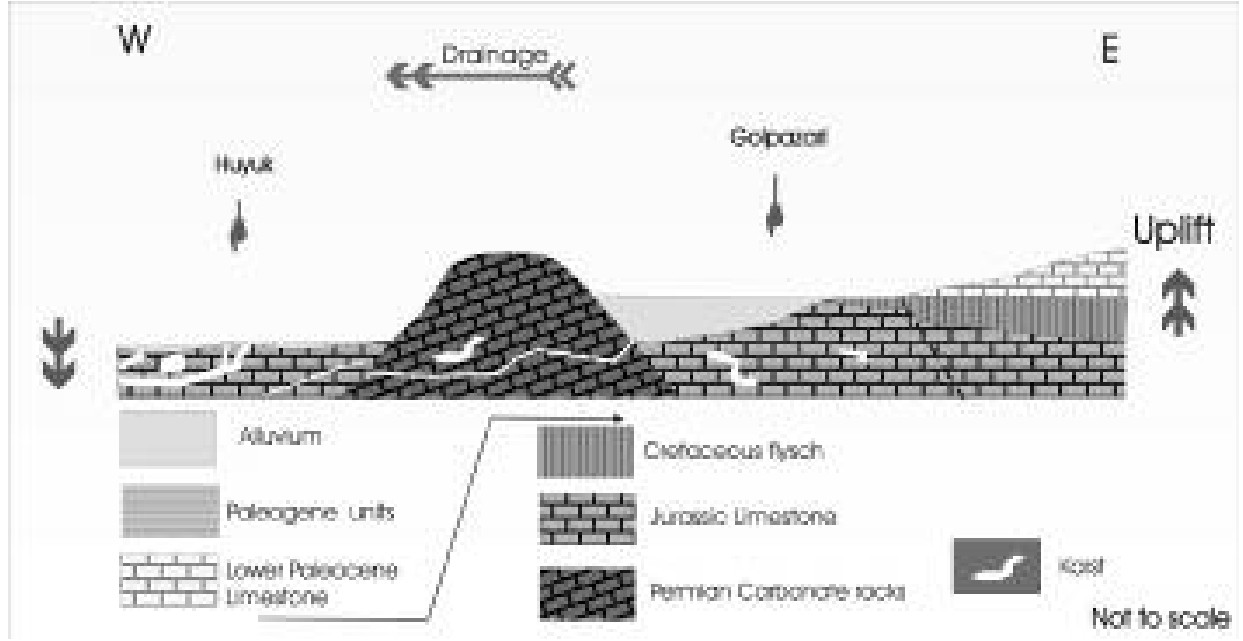

Figure 12. Stage of Surface Drainage and Clogging of Sinkholes (Late Pliocene)

paper using the geomeorphological hydrological/paleohydrological setting together with the neotectonic evolution and the corresponding paleogeographical development of the region. The method of the study was based on surface investigations. The model, however is to be testified by more detailed surface and subsurface investigations including localizing some archives of paleoclimatic, paleohydrological and paleoenvironmental records. 


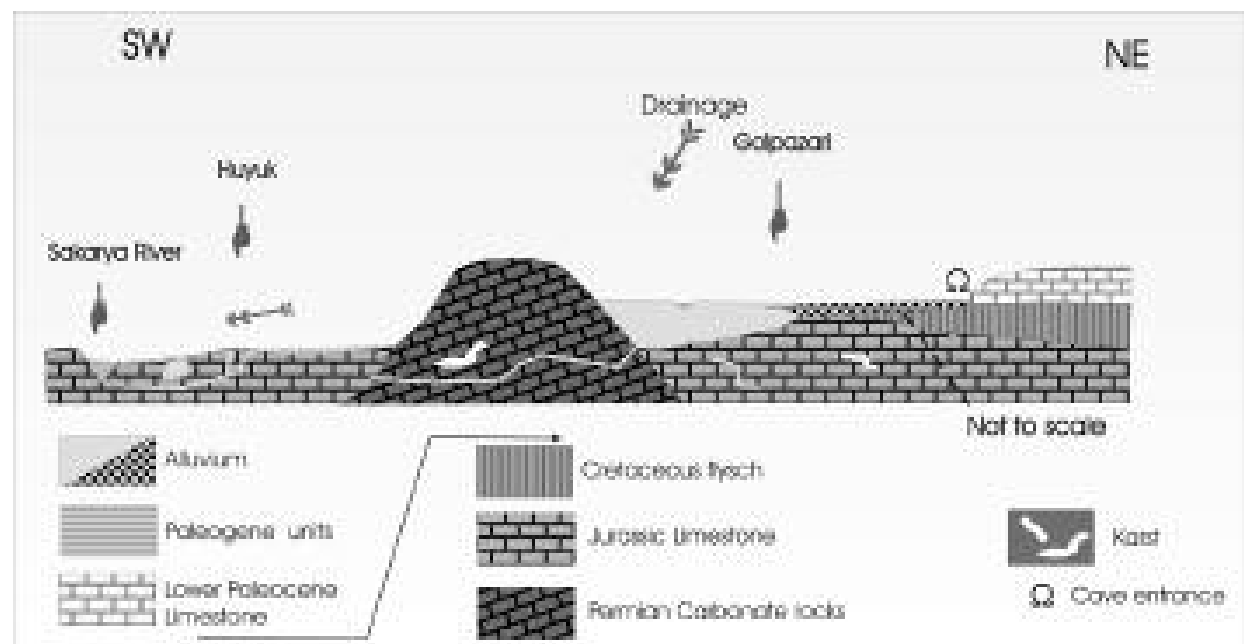

Figure 13. Emplacement of Sakarya River Capturing the Golpazari-Huyuk Karst System (Pleistocene-Present)

\section{Conclusions}

The karst evolution of the Golpazari-Huyuk system was reconstructed according to the geological, geomorphological, paleohydrological and karst morphological observations. The field observations were than evaluated on the basis of tectonic evolution and the coeval paleogeographical development of the study area.

Reconstruction of karst evolution of the Golpazari-Huyuk System suggests that karst development have started as early as Early Miocene in the Jurassic limestone and probably in Middle Miocene in the Paleocene limestone in the study area. Paleogeographically the region have not been invaded by marine water since Early Miocene and the system is located in the transition zone between the western extensional province and the very weakly active province. Reversal of drainage from W-E direction to E-W due to strong uplift at the Southeastern and Eastern Anatolia provided the energy gradient for karstification. The local erosion base, in the meantime, was the complementary major river for the Jurassic limestone karst and the impervious units for the Paleogene limestone. The karst became mature (holo karst) in Late Miocene probably until early Pliocene. It is evident that karstification was primarily controlled by the tectonics and the effect of climate was less pronounced. However, since Late Pliocene, this effect is more pronounced as the karst was soaked by fluviatile sediments. When Sakarya river entrenched its bed through the area, the climate became the major factor shaping the landscape and hydrology.

The study of this system provided some qualitative but important information in the course of description of the karst types in Turkey. According to the classification based on the geodynamic evolution of the territory proposed by Ekmekci (2003), the GolpazariHuyuk Karst system is a good example for the evolutionary-relict karst. This was demon- 
strated by the study of a local system such as the Golpazari-Huyuk system in the province. However, it is essential to produce quantitative data to identify more accurately the factors dominating karst processes in the region.

\section{Acknowledgements}

This study was performed within the framework of a project conducted by the Cave Research Group of the General Directorate of the Mineral Research and Exploration (MTA). The authors extend their sincere thanks to Dr. Leonardo Piccini for his invaluable contribution by his critics and comments on the paper. Thanks are due to Ms. Aylin Basal, Mr. Bülent Topuz, Ms. Sibel Demirci and Mr. Harun Aydin for their assistance in drawing and typing.

\section{References}

DSI. 1974 - Hydrogeological Investigation Report for Golpazari Plain, Ankara,

Ekmekçi M. 2003 - Review of Turkish Karst with Emphasis on Geologic and Climatic on Controls. Acta Carsologica, 32 (2): 205-218.

Göncüoglu M. C., Türkan N., Sentürk K., Uysal S., Ozcan A., Isık A., 1996 - Geological Properties of Structural Units Between Nallıhan and Sarıkaya in Sakarya. MTA Report No: 10094, Ankara (in Turkish)

Göncüoglu M.C., Turhan N., Sentürk K., Ozcan A., and Uysal S., 2000 - A geotraverse across NW Turkey: tectonic units of the Central Sakarya region and their tectonic evolution. In: Bozkurt E., Winchester J. \& Piper J.A., (Eds.) Tectonics and magmatism in Turkey and the Surrounding Area. Geol. Soc. London Special Publ. 173: 139-161.

MTA, 2002 - , 1/100 000 Scale-Sheet Adapazari H24, Ankara

Nazik L., Tork K., Acar C., Ozel E., Mengi H., Aksoy B., Tuncer K., Guneri I. N., Ekmekçi M., Basal A., 2000

- Natural caves of central Sakarya Basin (E of Eskisehir and Bilecik). MTA Report, Ankara (in Turkish)

Sengör A. M. C., Gorur N., Saroglu F., 1985 - Strike-slip faulting and related basin formation in zones of tectonic escape: Turkey as a case study. Society of Economic Paleontologists and Mineralogists, Special Publication 37: 227 - 264

Yigitbas E., Yilmaz Y., Bozcu M., Yilmaz K., 2004 - Morphotectonical evolution of the Armutlu peninsula and surroundings - NW Anatolia - Turkey; some major caracteristic of eastern Marmara region. Geological Society of America abstracts with Programs, Denver Annual Meeting (November 7/10, 2004), 36 (5): 148 